\title{
VISIT TO THE BRITISH MUSEUM (NATURAL HISTORY).
}

\author{
Saturday, February 27Th, I909.
}

Director: L. J. Spencer, M.A., F.G.S.

(Report by THE DIRECIOR.)

A PARTy of about forty met at 2.30 in the Mineral Gallery, where Mr. Spencer gave a demonstration on "Precious Stones."

Starting with the CHEMiCal ElEMENTS, the first and most important of the precious stones is diamond, which finds a place next to graphite, these two minerals being crystalline forms of carbon, and thus affording a most striking example of dimorphism. Diamond crystallizes as colourless, transparent octahedra, and is the hardest of all known substances, whilst graphite crystallizes as black, opaque, hexagonal scales, and is the softest of minerals ; all the other physical characters are widely different, the specific gravity, for example, being 3.5 and $2 \cdot 2$ respectively. Attention was drawn to the "Colenso" diamond, a pale yellow, perfectly developed octahedron weighing $\mathrm{I} 30$ carats; and to the glass models of famous diamonds, including that of the largest diamond known, the "Cullinan," of $3,025 \frac{3}{4}$ carats (about $\mathrm{I} \frac{\mathrm{l}}{3} \mathrm{lb}$. avoirdupois), found in 1905 , and now cut into a number of gems (weighing $516 \frac{1}{2}, 309 \frac{3}{16}, 92,62,18 \frac{3}{8}, 11 \frac{3}{4}$, etc., carats).

Passing by the sulphides and haloids to the OXIDES, corundum was taken as an example of a mineral species exhibiting a wide range of colour. When free from impurities and flaws, this mineral is perfectly colourless and transparent ("white sapphire"), and when these are present in large amount it is black and opaque (emery). The transparent gem-varieties of corundum may be red (ruby), yellow, green, blue (sapphire), or violet, these colours being due to the presence of traces of metallic oxides, principally of chromium and iron. Even in the same crystal there may be bands of different colours, as seen in the particoloured gems. Spinel and chrysoberyl are here also placed amongst the oxides, though frequently they are classed as aluminates. The red and blue colour-varieties of spinel may readily be mistaken for ruby and sapphire. A variety of chrysoberyl known as alexandrite is of interest in showing a green colour by daylight and a red colour by lamplight, this difference in colour being due to the very strong dichroism of the mineral ; and another variety (cymophane or cat's-eye) shows a chatoyant band of reflected light. Zircon (often classed with the silicates) is the densest of the precious stones, and is remarkable for the wide variation in specific gravity $\left(4^{\circ} \circ\right.$ to 47$)$. When heated, the crystals are 


\section{I $5^{8}$ VISIT TO THE BRITISH MUSEUM (NATURAL HISTORY).}

changed in colour, and often also in specific gravity. Crystals of cassiterite (tin-stone) when transparent and of a good colour have occasionally been cut as gems. Quartz, the most abundant of all minerals, is remarkable for the large number of semi-precious stones it supplies. The transparent, crystallized varieties include rock-crystal, cairngorm, citrine, amethyst, rose-quartz, etc. Quartz with enclosures of various kinds gives avanturine-quartz, quartzcat's-eye, and tiger-eye. Jasper is an impure, compact variety ; and chalcedony, with its many varieties (blood-stone, plasma, chrysoprase, sard, sardonyx, agate, onyx, carnelian, mocha-stone, moss-agate, etc.), is a cryptocrystalline form of quartz. Finally, amongst the oxides we have the hydrated form of silica, opal, of which there are also several varieties; the variety hydrophane shows a play of colours only when immersed in water.

The CARBONATES being all soft minerals are not suitable for use as precious stones, though the green copper carbonate (malachite) and a fibrous variety of calcite (satin-spar) are sometimes used in cheap jewellery.

Amongst the SILICATEs, the largest division in the classification, there are several minerals with a high degree of hardness, transparency, brilliant lustre and attractive colour, which fit them for use as precious stones. In the cases, cut examples are exhibited of phenacite, olivine (chrysolite and peridot), enstatite, bronzite and hypersthene, diopside, spodumene (the green hiddenite and the violet kunzite), jade, rhodonite, serpentine, topaz, andalusite (and chiastolite), kyanite, garnet (cinnamon-stone, pyrope, almandine, and demantoid), idocrase, jadeite, epidote, labradorite, oligoclase (sun-stone), orthoclase (moon-stone), beryl (emerald, aquamarine, and golden beryl), euclase, cordierite, tourmaline (rubellite, indicolite, and green tourmaline), axinite, lapis-lazuli, and sphene. Many of these minerals, though affording good gem-stones, are little known in the trade. Certain of them were taken as examples to illustrate the more important principles of mineralogy ; for instance, the isomorphism of the garnets, the pleochroism of cordierite, the hemimorphism and pyro-electrical character of tourmaline, etc.

Amongst the SUlPHATES, PHOSPHATES, etc., the only precious stone is turquoise, a compact, hydrous phosphate of aluminium coloured by copper and iron. Faceted examples of transparent, colourless beryllonite (a phosphate of beryllium and sodium) are, however, also exhibited.

Finally, amongst the ORGANIC COMPOUNDS we have the fossil resin amber, and the varjety of coal known as jet.

Attention was drawn to the artificially-prepared specimens of crystallized corundum of various colours, more especially of a rich ruby-red, which afford cut stones of excellent quality and of considerable size, differing from the natural stones only in their mode of origin. These are manufactured in large quantities from 
ammonium-alum in the flame of the oxy-hydrogen blowpipe, a small proportion of chromium-alum being added to supply the colouring matter.

In conclusion, the uses of methylene iodide, of the refractometer* and the dichroscope, for the discrimination of precious stones, were explained. The specific gravity $(3.33)$ of the heavy liquid methylene iodide $\left(\mathrm{CH}_{2} \mathrm{I}_{2}\right)$ may be reduced to any desired amount by the addition of benzene, and into such a mixture, with a specific gravity of $3 \cdot x$, three green stones-demantoid ("Uralian emerald"), sp. gr. 3.8 ; true emerald (beryl), sp. gr. $2{ }^{\circ}$; and green tournaline ("Brazilian emerald"), sp. gr. 3.I-were dropped: the first sank, the second floated, whilst the third remained suspended in the liquid.

The following works on precious stones were recommended : Prof. A. H. Church's excellent little handbook, and the larger work by Prof. Max Bauer, English translation by L. J. Spencer.

Mr. G. Potter then proposed a vote of thanks, which was heartily accorded to the director.

\title{
VISIT TO THE FLORISSANT EXHIBIT IN THE BRITISH MUSEUM (NATURAL HISTORY).
}

\author{
Saturday, March 6Th, Igog.
}

Director: Dr. F. A. Bather, F.R.S.

(Report by THE DIRECTOR : Published by permission of the Trustees of the British Museum.)

Aвour thirty members assembled in the Fossil Reptile Gallery, where there had been placed on temporary exhibition a case of fossil animals and plants from the Miocene Lake-basin of Florissant.

Florissant is a small town on the Colorado Midland Railway, sixty miles south-south-west of Denver, and about thirty miles west-north-west of Colorado Springs. It lies some 8,000 ft. above the sea on the floor of a broad valley, the surrounding hills being rounded off and rarely, within a radius of seven miles, rising more than a thousand feet above Florissant itself. But fifteen miles to the east are the summits of the Colorado Range with Pike's Peak ( $\mathrm{I}_{4}, 083 \mathrm{ft}$.). The country rock generally is granite. The climate is dry, the vegetation of an arid character, and the streams small.

Formerly the district seems to have been drained by a stream

- A specially handy form of instrument, designed by Dr. G. F. Herbert Smith, with which the refractive indices of a faceted stone can be read directly on a scale. 